\title{
KETERKAITAN FAKTOR OSEANOGRAFI DENGAN SUMBER DAYA IKAN PELAGIS
}

\section{Bagian I: Deskripsi Faktor Fisik, Abiotik, dan Penyebaran Agregasi Akustik di Laut Flores}

\author{
Bambang Sadhotomo*) dan Subhat Nurhakim*)
}

\begin{abstract}
ABSTRAK
Berlandaskan anggapan bahwa sumber daya ikan pelagis kecil menempati wilayah perairan yang luas, mencakup perairan Laut Flores, sehingga peningkatan produksi ikan masih layak dilaksanakan. Berbasis pada data survai akustik dan oseanografi yang dikumpulkan pada bulan November 1999, penelitian ini bertujuan merangkum berbagai informasi mengenai dinamika spasial agregasi ikan dan hubungannya dengan karakteristik perairan yang diperlukan dalam pengembangan penangkapan. Data menunjukkan bahwa densitas akustik di perairan ini relatif rendah dibandingkan dengan wilayah perairan di sebelah Barat, kecuali di beberapa area marginal di sekitar selat dan gugus terumbu karang. Profil massa air, kandungan nutrien dan konsentrasi plankton serta larva memberi petunjuk adanya fenomena munculnya area marginal yang subur di beberapa lokasi selama penelitian.
\end{abstract}

ABSTRACT: On the relationship between ocenographic factors and pelagic abundance. Part 1: Description of physical, biotic factors and distribution of acoustic aggregation in the Flores Sea. By: Bambang Sadhotomo and Subhat Nurhakim.

This study is based on the acoustical and oceanographycal characteristics observed during a survey conducted in November 1999. The objective was to synthesize various information being generated by hydrographic and acoustic data. Longitudinal profile of the area was figurized by performing graphical analysis on the salinity, temperature, nutrient, and acoustic data, as well as on plankton and larva sampling data. The data showed that the acoustic density in this area was considered to be lower than those of the Java Sea. High fertile area and concentration of aggregation of trace were observed in the marginal area that was characterized by a turbulence and internal wave near the passage of the shifting of water masses from northern area to the Indian Ocean.

KEYWORDS: pelagic, Flores, oceanography, acoustic, and aggregation

\section{PENDAHULUAN}

Sumber daya perikanan pelagis di kawasan Indonesia bagian barat telah cukup lama dimanfaatkan. Tekanan penangkapan dinilai telah cukup tinggi, terutama sejak perkembangan pesat pukat cincin di Laut Jawa sejak 20 tahun terakhir. Suatu upaya untuk tetap mempertahankan atau meningkatkan produksi perikanan dapat dicapai melalui perluasan dan pengembangan daerah penangkapan baru di kawasan timur. Sudah dapat dipastikan bahwa stok ikan pelagis kecil yang dominan di perairan Laut Cina Selatan dan Laut Jawa berasal dari satu kesatuan populasi sebagaimana dapat ditafsirkan dari hasil penelitian genetik dari jenis Decapterus macrosoma (Perin, 1998)

Namun toleransi yang cukup tinggi terhadap perubahan salinitas memungkinkan jenis-jenis ikan pelagis kecil utama yang tertangkap di paparan Sunda menempati perairan di kawasan timur. Sementara itu, tekanan eksploitasi yang rendah di Laut Flores dan kurangnya pengetahuan akan penyebaran jenis-jenis ikan pelagis kecil di perairan ini melatarbelakangi penelitian ini. Berkenaan dengan hal tersebut, dapat dikemukakan bahwa sebagian besar dari stok menempati wilayah perairan di luar Laut Jawa (Sadhotomo, 1998)

Untuk itu, penggambaran pola penyebaran spasial yang mengacu pada informasi geografis perlu dilaksanakan untuk memberi landasan bagi penentuan taktik penangkapan di masa mendatang. Hal di atas memberi suatu peluang untuk pengembangan penangkapan dan perlunya mempersiapkan informasi yang akurat untuk mengantisipasi berbagai masalah potensial dalam pengelolaan di masa mendatang. seperti interaksi antar perikanan di wilayah barat dan timur. Untuk itu perlu informasi relevan yang menyangkut dinamika agregasi ikan yang merupakan

Peneliti pada Balai Penelitian Perikanan Laut 


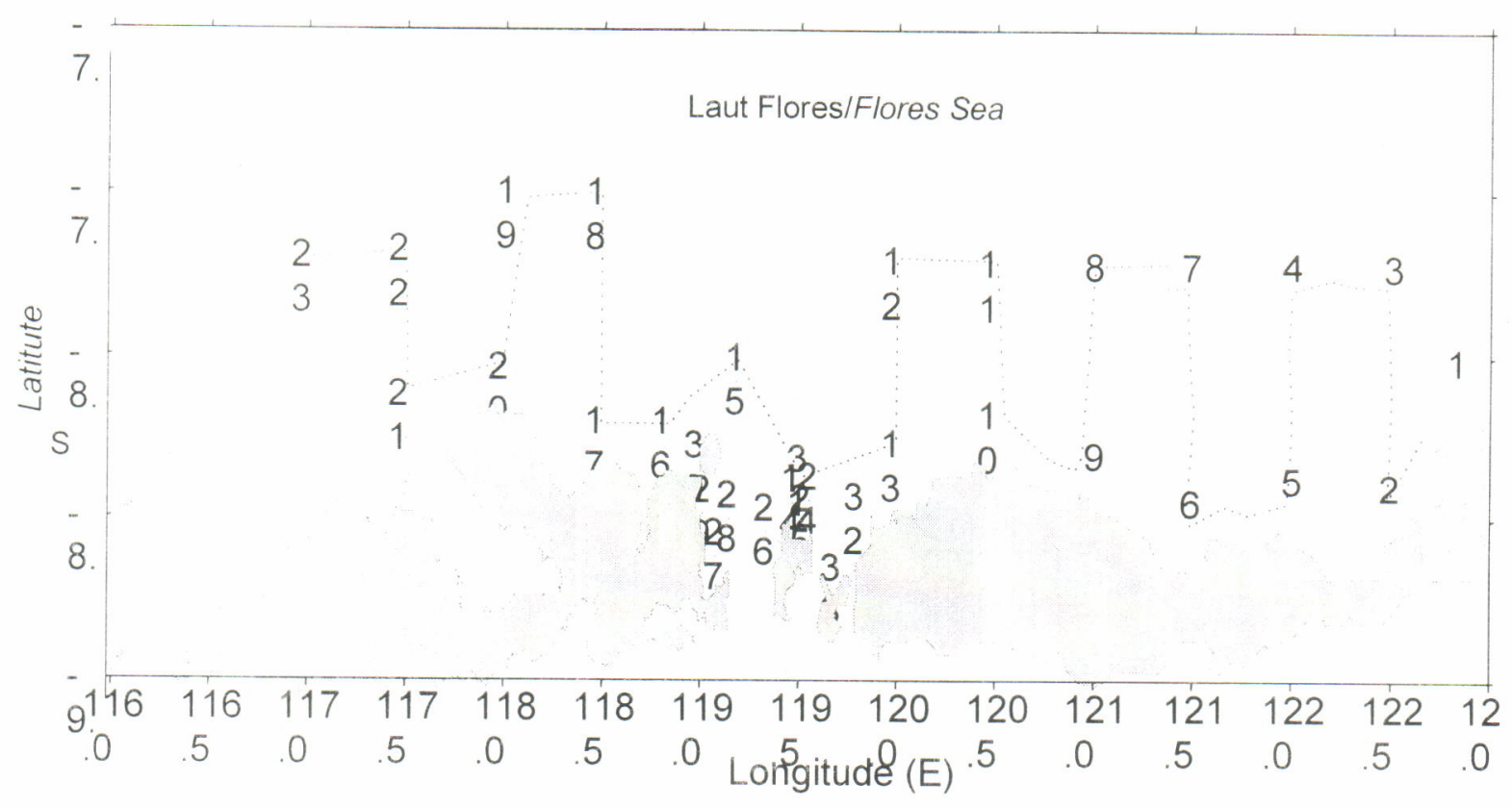

Gambar 1a. Area yang dicakup dalam penelitian (garis terputus adalah cruise track KM Mutiara 4, nomor adalah stasiun oseanografi dan plankton)

Figure 1a. Area covered during survey (dotted line are the cruise track of R/v Mutiara 4, figure numbers are oceanographic stations)

basis bagi protokol pengendalian dan pengoperasian penangkapan secara efisien. Makalah ini merupakan bagian dari studi menyeluruh yang bertujuan merangkum segala informasi berkaitan dengan hal tersebut di atas

\section{BAHAN DAN METODE}

Penelitian ini berbasis pada data primer yang dikumpulkan selama pelayaran akustik dan oseanografi di Perairan Laut Flores. Sebagian besar data yang digunakan dalam makalah ini bersumber pada pelayaran akustik dengan KM Mutiara 4 pada bulan November 1999. Track khusus baik yang dilaksanakan dengan kapal penelitian maupun kapal komersial di perairan sekitar Selat Sape dan Kepulauan Komodo melengkapi studi ini (Gambar 1a dan $1 b)$.

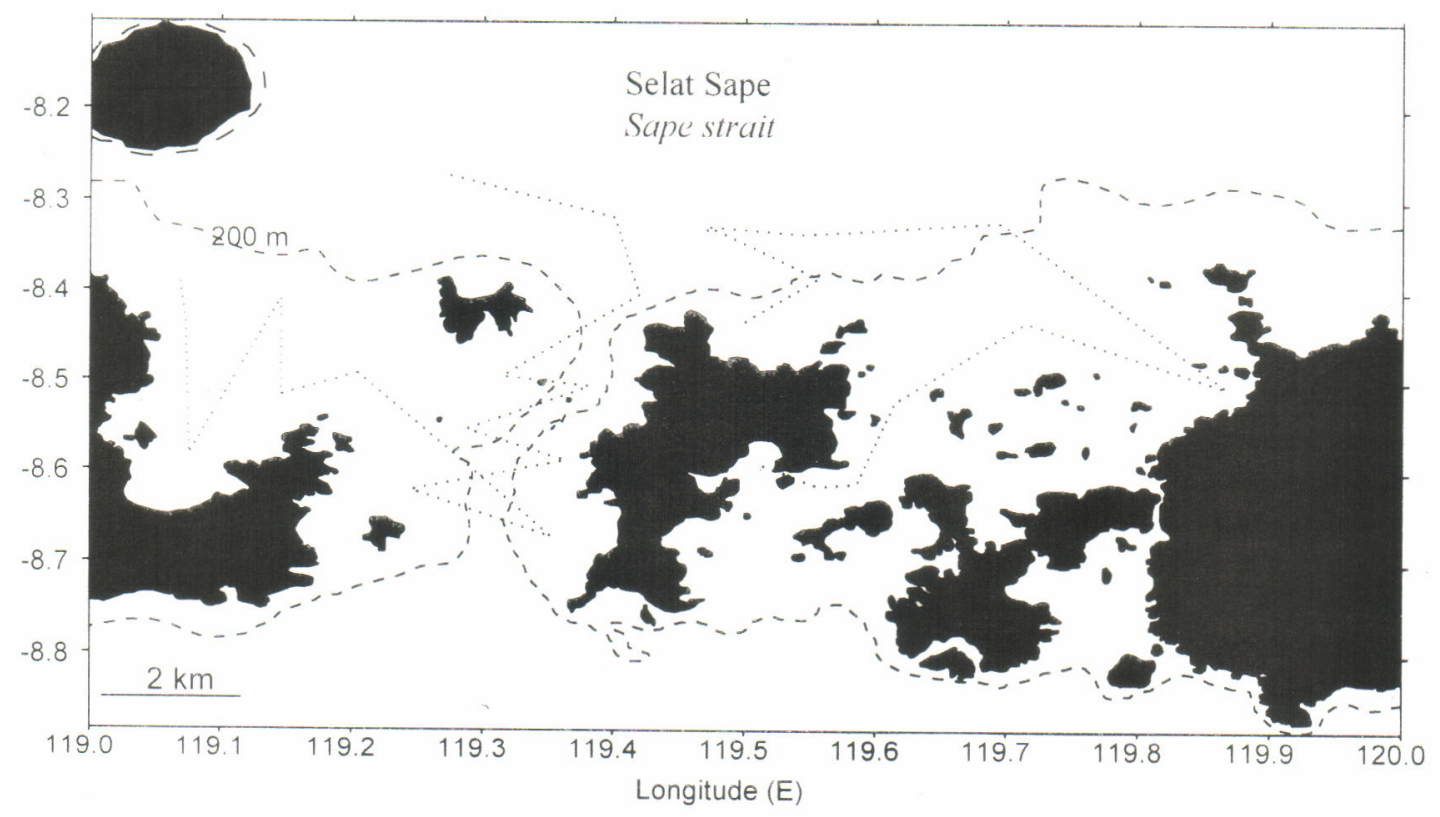

Gambar 1b. Track dan stasiun oseanografi untuk studi khusus di Selat Sape

Figure 1b. Cruise track and oceanographic stations made during special cruises in Sape Strait 


\section{Akuisisi data}

Dua bentuk data utama telah diperoleh selama periode pengamatan, yaitu:

(a) Data akustik dan target Strength yang dikumpulkan dengan echosounder Biosonic dan Simrad EY500

(a) Salinitas/Salinity

Perairan dekat pantai / Near shore line

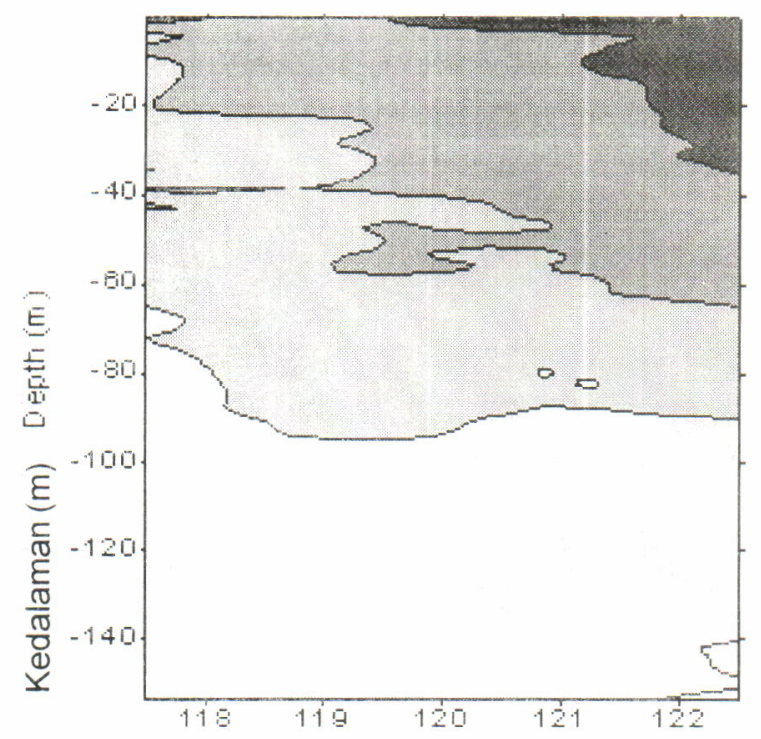

yang bekerja masing-masing pada frekuensi 120 $\mathrm{kHz}$ dan $38 \mathrm{kHz}$

(b) Data oseanografi:

- fisik : salinitas, suhu, dan nutrien (DO, nitrat, dan fosfat)

- plankton dan larva

Garis bujur / Langitude (E)

(b) Suhu/Temperature

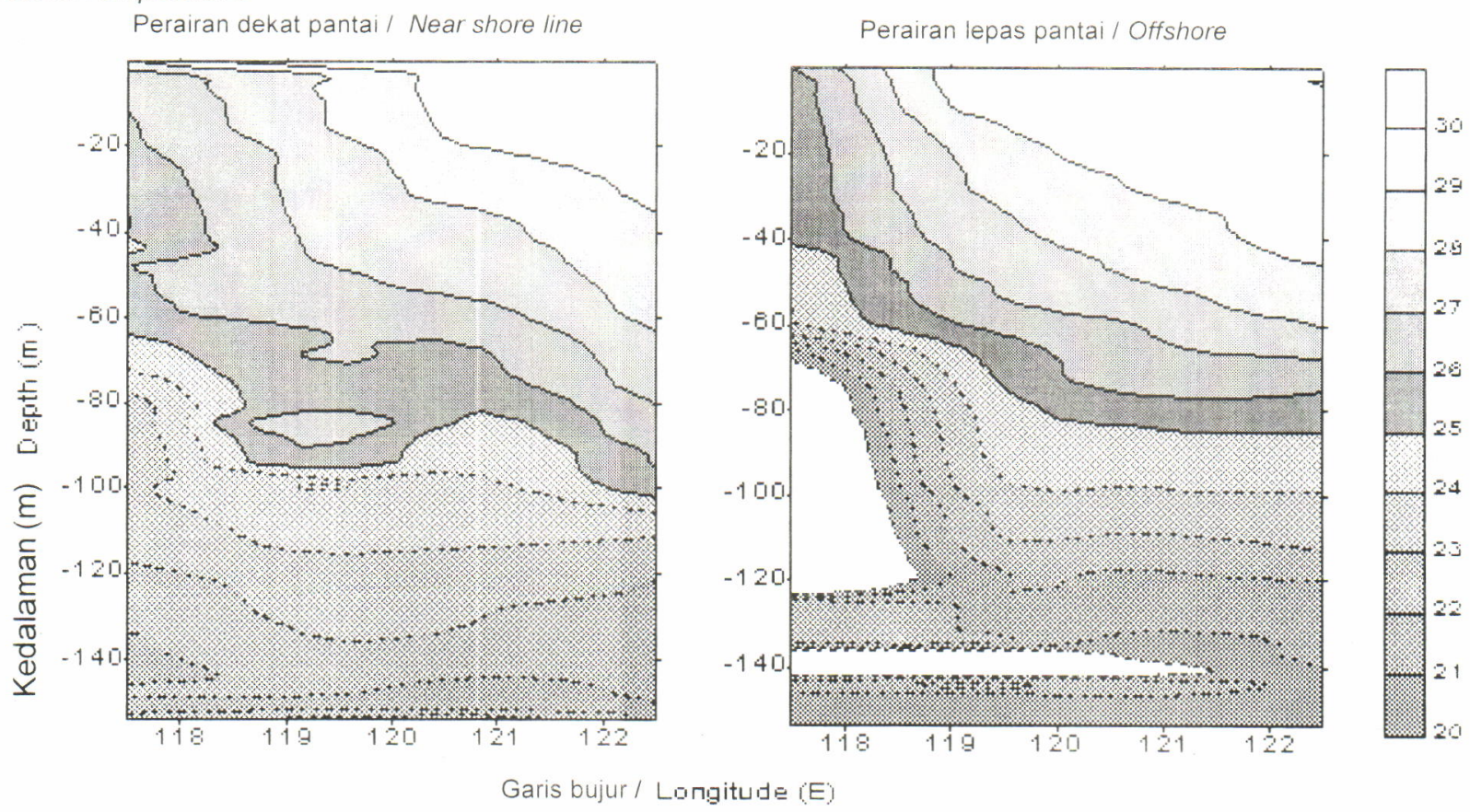

Gambar 2. Profil salinitas dan suhu Laut Flores dalam area cakupan track (diagram sebelah kiri diturunkan dari stasiun pengamatan di daerah pantai, sebelah kanan dari perairan lepas pantai)

Figure 2. Salinity and temperature profile in the area covered during cruise (left diagram presents near shore stations, right side, presents offshore ones) 


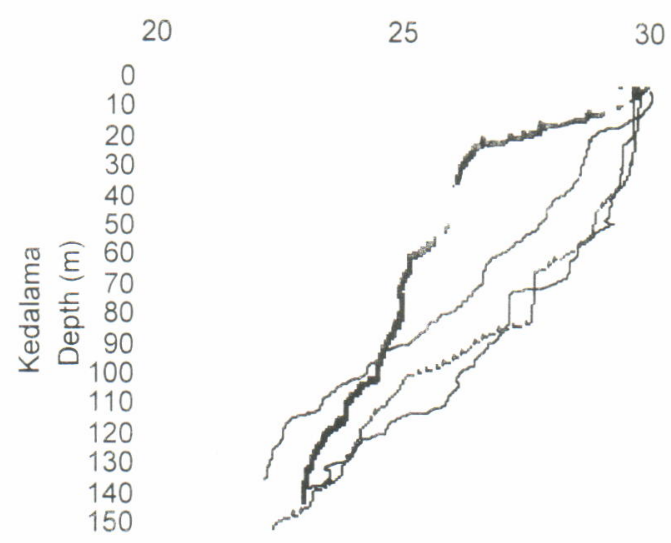

Gambar 3. Diagram yang menunjukkan nilai suhu menurut kedalaman di beberapa lokasi Figure 3. Showing temperature-depth relationship in various stations

Protokol penggunan aparatus dan pengambilan contoh mengikuti cara-cara yang baku. Hasil observasi lain berupa pengamatan kondisi terumbu karang akan disajikan dalam makalah terpisah. Analisis deskriptif berbasis pada presentasi grafikal merupakan dasar bagi penafsiran data dan penyusunan informasi. Teknik dalam analisis dan teori yang melatarbelakanginya seperti krigging, interpolasi, matematik-statistika, dan sebagainya telah banyak disajikan dalam berbagai literatur.

\section{HASIL DAN BAHASAN}

\section{Profil massa air}

Dalam skala luas, profil salinitas dan suhu digambarkan sebagai contour menurut kedalaman dan bujur. Gradien vertikal di lokasi lepas pantai merupakan fenomena yang umum terdapat di wilayah perairan di Indonesia, yaitu suhu yang rendah mencerminkan lapisan massa air dengan kadar garam yang lebih tinggi (Wyrtki, 1956). Namun di lokasi dekat pantai dan selat, pelapisan massa air lebih disebabkan oleh pertemuan dua massa air dari utara dan Samodera Hindia. Selat Sape dapat dianggap sebagai salah satu passage aliran massa air dari Samodera Pasifik ke Samodera Hindia, sebagaimana Laut Timor dan Selat Makassar. Lokasi perairan dengan kondisi khusus dapat diharapkan merupakan tempat berkumpulnya ikan tertentu dalam jumlah besar dengan pola agregasi yang spesifik (Marchal et al., 1993).

Dalam penelitian ini lokasi perairan tersebut dapat dicirikan oleh hubungan suhu dengan kedalaman yang ditunjukkan oleh termoklin pada kedalaman kurang dari $100 \mathrm{~m}$ yang terdapat di Selat Sape. Percampuran massa air dan umbalan merupakan kejadian yang sering terlihat secara visual dan akustik selama penelitian. Berbagai pola spesifik teramati seperti Deep Scattering Layer, pola gelombang dari gelembung udara di lapisan kedalaman tertentu dapat diamati dengan jelas melalui alat akustik di sekitar slope dalam selat. Fenomena ini terekam dengan baik, namun masih memerlukan pencarian lebih lanjut untuk memisahkan dari data yang dibangkitkan oleh trace atau agregasi ikan. Sifat massa air di lokasi yang relatif sempit ini ditunjukkan oleh perubahan ekstrim kandungan parameter oseanografi seperti nutrien. oksigen terlarut dan sebagainya yang selanjutnya diikuti oleh konsentrasi plankton dan ikan.

Penggambaran profil nutrien (dalam hal ini adalah nitrate dan phosphate) dengan cara yang sama (Gambar 4) memberi petunjuk adanya fenomena tersebut di atas. Penyuburan di lokasi tertentu dapat ditunjukkan oleh nilai kandungan nutrien yang relatif tinggi pada kantong-kantong massa air di sekitar bujur 119 derajat BT (dekat mulut Selat Sape) dan 121 derajat BT (di utara Teluk Maumere). Pengangkatan massa air dari lapisan bawah dengan pola semacam upwelling belum dapat dibuktikan dari penelitian ini, mengingat profil vertikal diturunkan dari pengukuran hanya sampai kedalaman $150 \mathrm{~m}$ di bawah permukaan.

\section{Kelimpahan ikan}

\section{Agregasi}

Indeks kelimpahan digambarkan berdasarkan reverberasi akustik yang dinyatakan dalam satuan $\mathrm{Sa}$ $\left(\mathrm{mV}^{2}\right)$ pada setiap 1.000 ping. Bentuk pengukuran lain seperti target per mil persegi dan sebagainya dianggap sebagai proporsional dengan satuan tersebut sehingga analisis cukup dilakukan terhadap pengukuran pada satuan Sa. Penggambaran kelimpahan diseragamkan dengan diagram contour profil massa air (Gambar 5). Dalam cakupan area skala luas, jumlah dan nilai agregasi target dinilai rendah dan tidak memberi indikasi yang jelas 


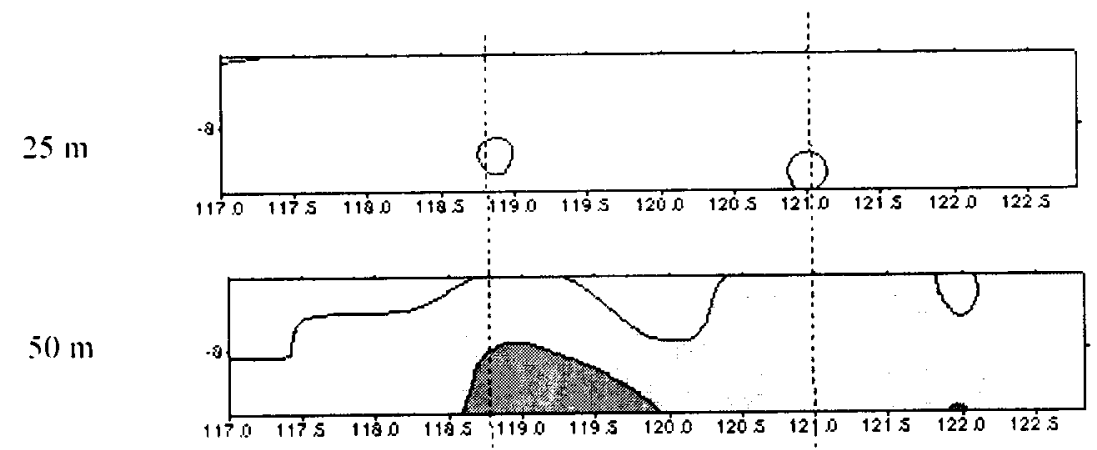

$100 \mathrm{~m}$

$150 \mathrm{~m}$

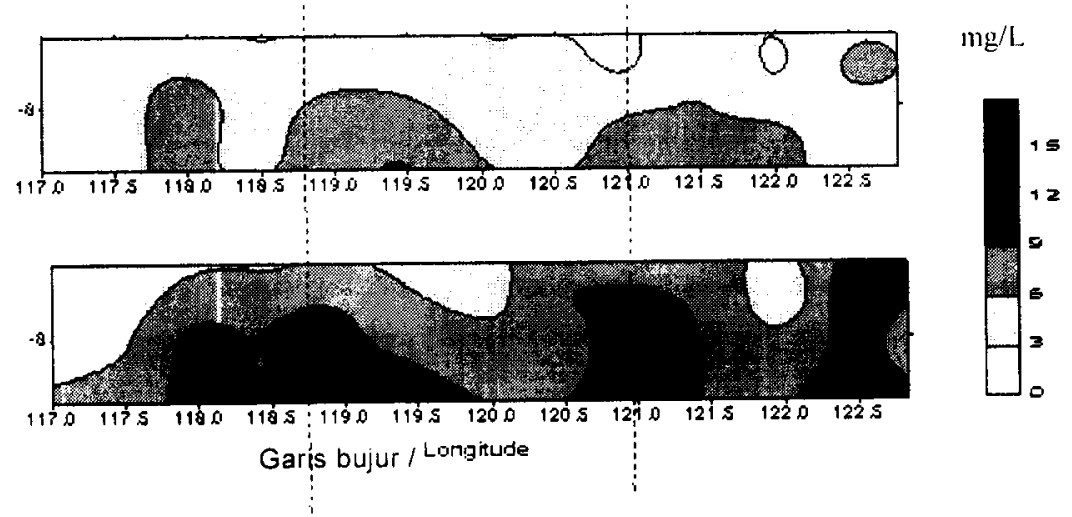

$25 \mathrm{~m}$

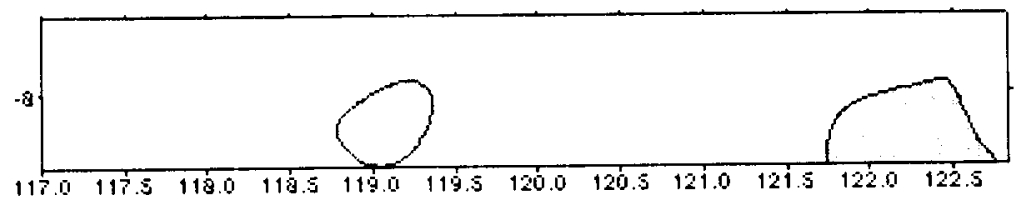

$50 \mathrm{~m}$

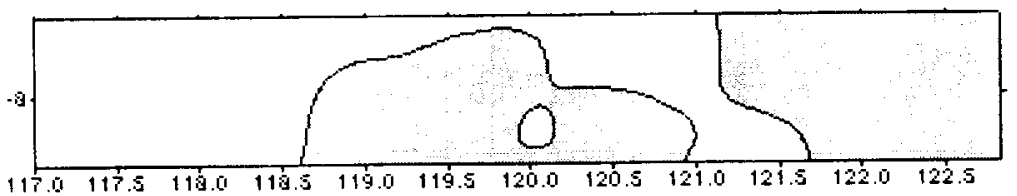

$100 \mathrm{~m}$

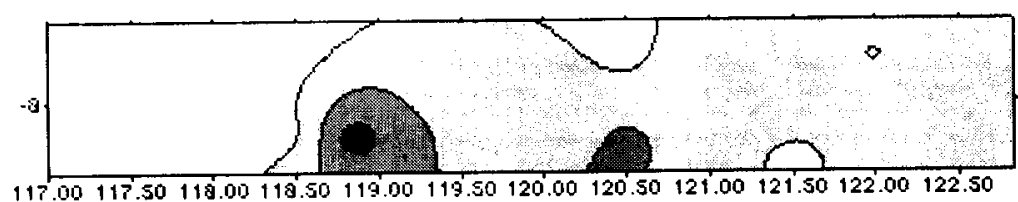

$\mathrm{mg} / \mathrm{L}$

$117.00117 .50118 .00118 .50119 .00119 .50120 .00120 .50121 .00121 .50122 .00 \quad 122.50$

$150 \mathrm{~m}$
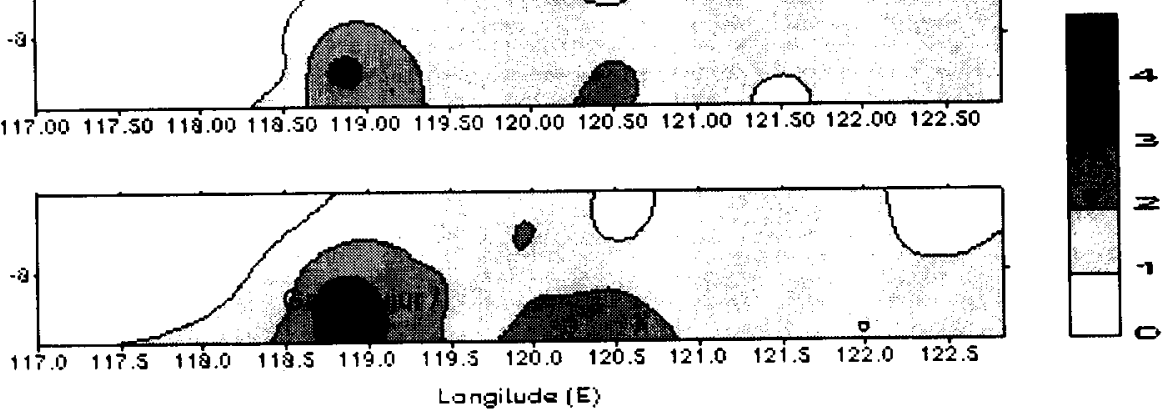

Gambar 4. Kontur kandungan nitrat dan fosfat menurut kedalaman dan bujur (garis terputus adalah garis bantu untuk menunjukkan bujur yang sama)

Figure 4. Counturs showing nitrate and phosphate content by depths (dotted line presents the same longitude) 


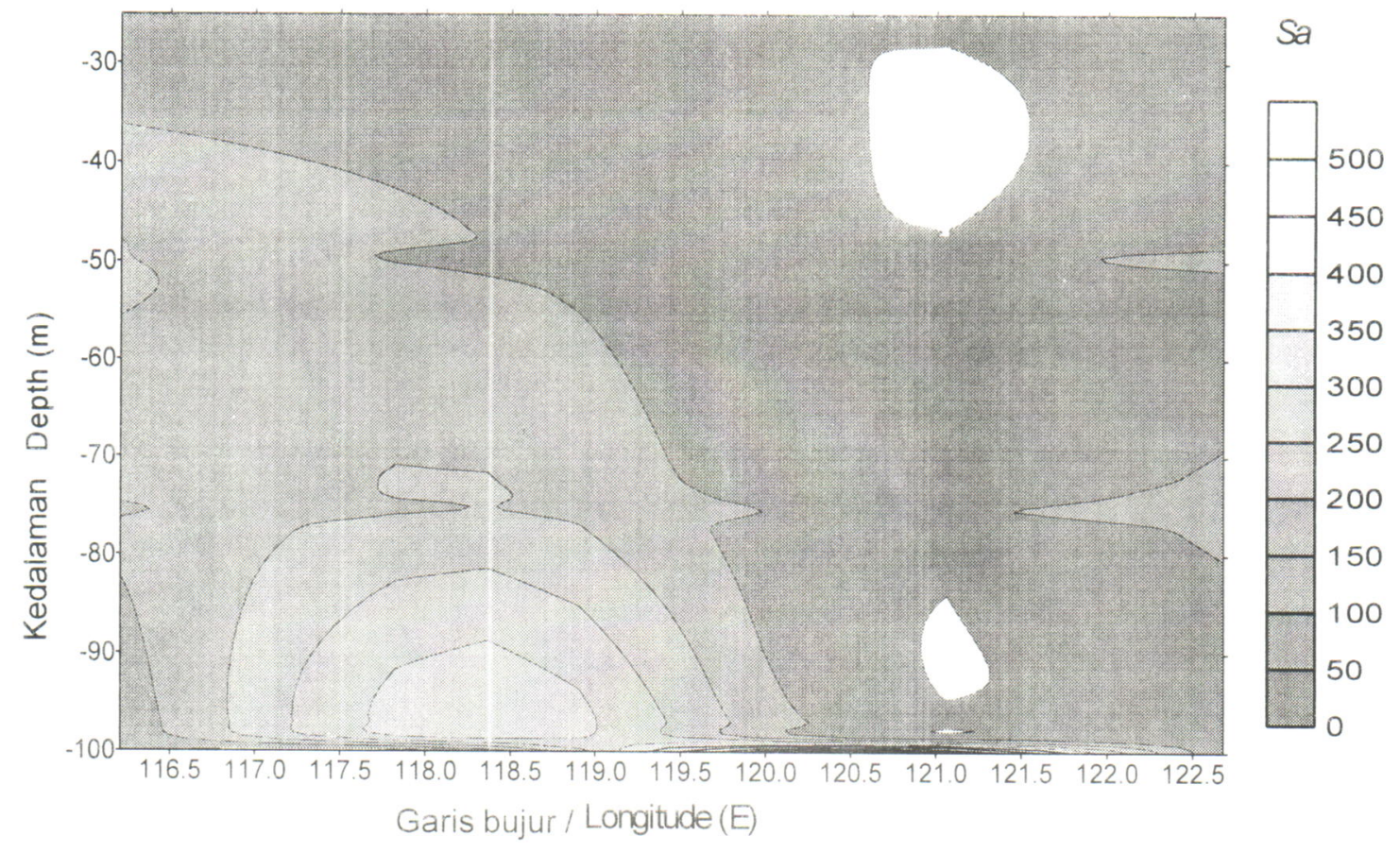

Gambar 5. Kontur penyebaran indeks kelimpahan target akustik dalam area yang tercakup track Figure 5. Countur showing the distribution of acoustic density in the area covered by the tracks

mengenai kecenderungan ikan pelagis kecil menempati perairan ini sebagai habitat utama. Kecenderungan ikan menempati lapisan yang lebih dalam terlihat dengan jelas pada Gambar 6 dan dipertegas dengan contoh yang diambil dari dua lapisan, yaitu lapisan dekat permukaan (7-25 m) dan lapisan 75-100 m. Stratifikasi vertikal lebih nyata dibandingkan dengan horizontal, walaupun kecenderungan agregasi yang lebih padat terdapat pada lokasi tertentu, seperti di sekitar gugus karang di utara Pulau. Moyo dan Selat Sape. Sebagai pembanding, pada musim yang sama jumlah dan ukuran agregasi di Laut Jawa bagian timur relatif lebih besar sebagaimana ditunjukkan hasil pengukuran penelitian sebelumnya (Petit et al., 1995; Sadhotomo, 1998).

\section{Target Strength}

Secara umum nilai hasil pengukuran target strength menunjukkan bahwa ukuran organisme yang terkena pancaran akustik selama penelitian ini relatif kecil dibandingkan dengan nilai pengukuran di Laut Jawa pada musim yang sama walaupun beberapa target dengan ukuran relatif besar terdapat dalam jumlah sedikit di sebelah timur area yang tercakup dalam survai. Sebagian besar nilai pengukuran target strength berkisar antara antara $-47 \mathrm{~dB}$ sampai $-50 \mathrm{~dB}$. Dengan mengadopsi hubungan panjang ikan sama dengan $20 \log$ TS + konstanta, maka ukuran ikan yang terdapat di perairan ini relatif lebih kecil, yaitu berkisar antara 8-12 cm. Nilai ini masih lebih rendah dari komposisi panjang jenis utama yang ditangkap pukat cincin di perairan sebelah timur Laut Jawa yang berkisar antara 12-15 cm dalam panjang cagak dan pengukuran TS yang berkisar antara -44 dB hingga $38 \mathrm{~dB}$ (Sadhotomo, 1998).

\section{Distribusi plankton dan larva}

Pengumpulan contoh larva dan plankton di stasiunstasiun oseanografi memberi dukungan pada kemungkinan adanya lokasi tertentu sebagai daerah asuhan (nursery ground). Konsentrasi kepadatan telur dan larva ikan di lokasi yang sama dengan daerah yang relatif subur seperti telah dijelaskan di atas memberi petunjuk bahwa sebagian perairan Laut Flores merupakan daerah pemijahan berbagai jenis ikan, walaupun masih diperlukan penegasan jenis atau spesies larva tersebut melalui identifikasi yang lebih rinci (Gambar 7)

Distribusi plankton secara kasar (yang dinyatakan dalam jumlah individu seluruh spesies) jelas berkaitan dengan kandungan nutrien seperti yang digambarkan 

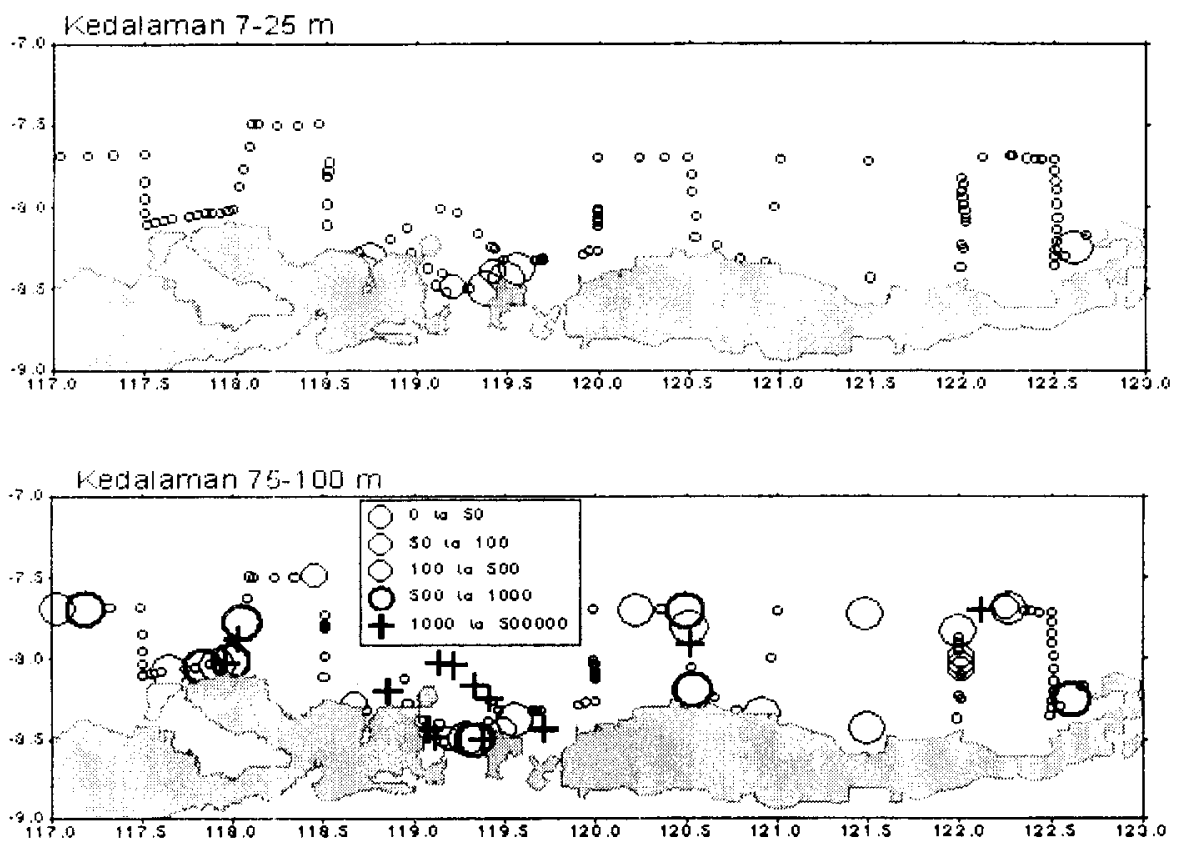

Gambar 6. Penyebaran indeks kelimpahan pada dua lapisan berbeda Figure 6. Distribution of abundance indice in two different layers
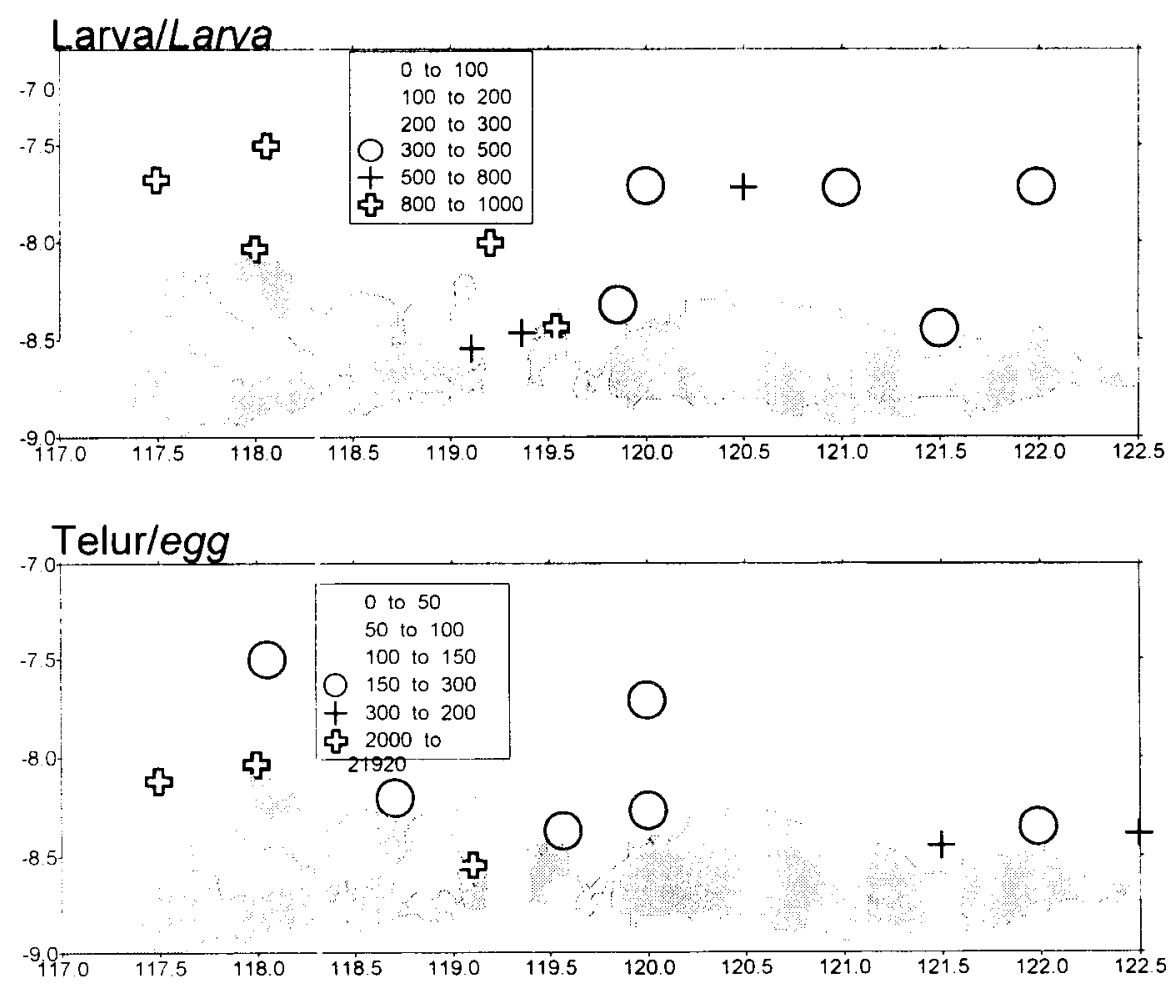

Gambar 7. Penyebaran indeks kepadatan larva dan telur ikan Figure 7. Distribution of eggs and lanae 
dalam Gambar 8. Hal ini merupakan fenomena umum yang tidak memerlukan elaborasi lebih lanjut. Peran plankton dalam kehidupan ikan dalam stadium awal sangat nyata terutama dalam hubungannya dengan pemangsaan. Namun bagaimanapun juga, belum diperoleh data yang memadai mengenai fluktuasi musiman kelimpahan plankton dan musim pemijahan (b) Berbagai lokasi tertentu massa air yang subur berkaitan dengan pola aliran dari utara dan pertemuan dengan massa air dari selatan, serta pengaruh dari gugus terumbu karang. Deep scattering layer, internal wave dan turbulence lainnya yang muncul sebagai akibat dari percampuran kedua massa air tersebut merupakan fenomena

a. Zooplankton/Zooplankthon

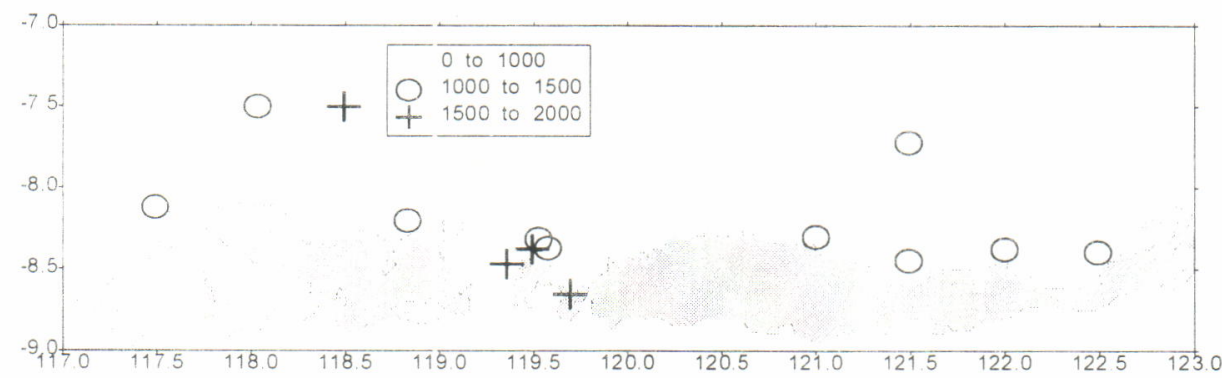

b. Fitoplanton/Phytoplanton

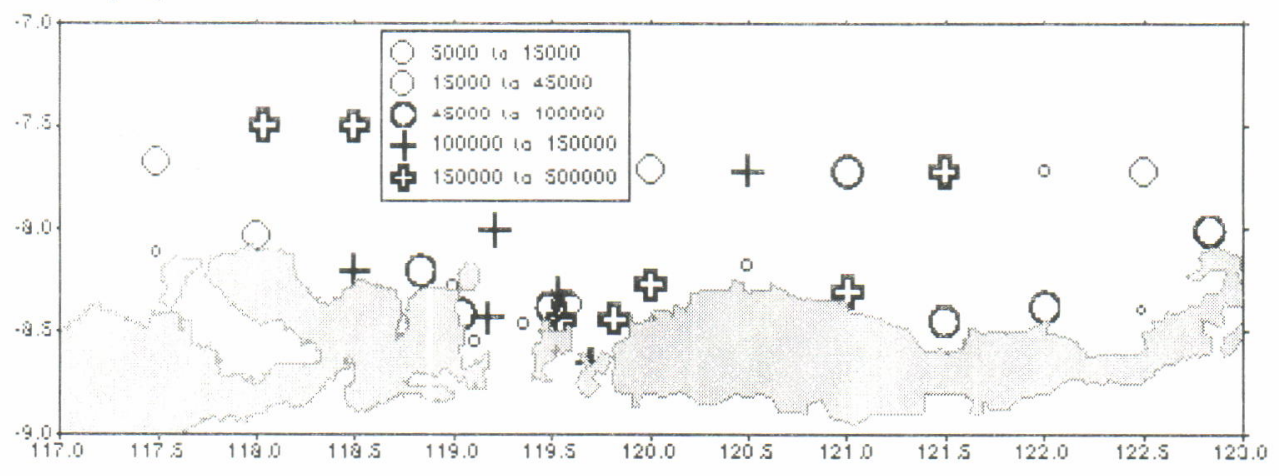

Gambar 8. Penyebaran horizontal Fitoplanton dan zooplankton

Figure 8. Distribution of the phytoplankton and zooplankton

di perairan ini sehingga memungkinkan untuk menentukan bentuk kecenderungan hubungan tersebut. Secara sederhana, hubungan nutrien-plankton-larva dengan kondisi perairan merupakan titik tolak untuk melaksanakan penelitian lebih lanjut

\section{KESIMPULAN}

Informasi yang dapat dirangkum dari berbagai pengamatan tersebut mengarah pada dua hal, yaitu: (1) kesimpulan yang berkaitan dengan pola ruaya dan agregasi, (2) berkenaan dengan perilaku ikan sebagai respons terhadap kondisi oseanografis

(a) Dinamika penyebaran spasial dan pola penggerombolan ikan pelagis cenderung mengikuti gradien utara-selatan searah dengan pergeseran massa air. Konsentrasi biomassa cenderung menempati lapisan yang relatif dalam yang memungkinkan menghasilkan daerah marginal. Peran terumbu karang dan kondisi marginal di lokasi tertentu dalam kehidupan ikan pada stadia awal merupakan isu yang relevan untuk penelitian lebih mendalam.

\section{DAFTAR PUSTAKA}

Marchal, E., Gerlotto, F \& Stequert, B. 1993. On the relationship between scattering layer, thermal structure and tuna abundance in Eastern Atlantic Equatorial Current System. Oceanologica Acta. 16(3):261-272.

Perrin, C. 1998. Phylogénie de l'ADN Mitochondrial, Structure Géographique et Reconstruction de l'histoire Evolutive des Populations du Complexes D'espèce Decapterus cf. russelli Dans le Sud-est Asiatique. Mem. DEA. Univ. Mediterranee Aix-Marseille II. ORSTOM/lab. Génome et Populations, CNRS UPR 9060. $43 p p$ 
Petit, D., Gerlotto, F.and Petitgas, P. 1995. Data stratification and pelagic fish density evaluation in the Java Sea. The Fourth Asian Fishery Forum. Beijing, Oct. 1995. $5 p p$

Sadhotomo, B, 1998. Bioécologi des princpales èspeces pèlagiques exploiteés en mer de Java. Université de Montpellier II. Tèhse de docteur. 365 pp.
Wyrtki, K. 1956. Monthly charts of sea surface salinity in Indonesian and adjacent waters. J. CIEM, 21, 268279. 